\title{
Legitimacy, Development and Sustainability: Understanding Water Policy and Politics in Contemporary China
}

\author{
Scott M. Moore
}

\begin{abstract}
More so than for other countries, the management of China's water resources is an important aspect of its policy and politics, yet existing scholarly attempts to understand this importance are scattered among a wide range of sub-literatures that lack a unifying theoretical framework. This article attempts to identify common themes and features of the relationship between water, politics and governance in contemporary China by examining how this relationship has unfolded in historical perspective. It identifies three basic objectives that have shaped the politics and governance of China's water resources over time: legitimacy, economic development and environmental sustainability. These objectives map, though imperfectly, onto different periods in the history of the People's Republic of China, thereby highlighting how they have evolved. Together, these objectives explain policies towards, and the politics of, water resources in contemporary China. This understanding shows that water both shapes and reflects Chinese politics, and highlights the need for a theoretically coherent sub-literature on Chinese water policy and politics.
\end{abstract}

Keywords: China; water; water governance; political economy; environment; sustainability

One of the great recurring questions in the study of Chinese politics, periodically raised and left unanswered, is what significance the management of China's water resources holds for its politics and governance writ large. The suggestion of such a relationship is ancient: the 4th-century scholar Guan Zhong 管仲 famously believed the effective management of water to be the key to maintaining social order, and aphorisms like "To rule effectively, one must first control the water” (shanzhi guo zhe, bi xian zhishui 善治国者 必先治水) litter the history of Chinese political thought. ${ }^{1}$ At the same time, water resource issues, although never far from the minds of China's post-1949 rulers, have become increasingly prominent since the ascension of former hydraulic engineer $\mathrm{Hu}$ Jintao 胡锦涛,

\footnotetext{
* University of Pennsylvania. Email: scottm@alumni.princeton.edu.

1 Ball 2017; Rong 2013.
} 
and continue to remain salient under his successor, Xi Jinping 习近平. During this period, China has embarked upon a flurry of dam-building and established the world's only cap on total national water consumption, even as senior leaders have grown increasingly concerned about the potential for severe water pollution to stoke social unrest. ${ }^{2}$

The unsettled nature of the relationship between water, politics and governance in China therefore bears continued practical as well as scholarly significance. But, despite the acknowledged value of studying water policy and politics in China, both for its own sake as well as a window into China's broader politics and governance, existing scholarly accounts remain discordant both in their conceptual approach and assessment. At least three primary themes are evident in the extant scholarly literature on water, politics and governance in contemporary China. ${ }^{3}$ The first is that the state uses and manipulates water as a deliberate strategy of rule, preferentially supplying it to favoured areas and denying it from seditious or disloyal ones. This message is central to Chao-ting Chi's landmark Key Economic Areas in Chinese History, ${ }^{4}$ and is also reflected in Karl Wittfogel's much-discounted claim that the need to mobilize large labour forces to build and maintain water control systems helps to account for the supposed primacy of authoritarianism in non-Western political history. ${ }^{5}$ Similar arguments can be found in more recent accounts of Chinese water supply projects. ${ }^{6}$ The second, closely related, theme is that in seeking to control, channel and manage water, the state in fact wreaks environmental and social destruction. This theme features prominently in a growing critical geography literature, which focuses on China's large infrastructure projects, ${ }^{7}$ as well as in a burgeoning literature on Chinese riparian environmental history. ${ }^{8}$

A third theme holds, in contrast, that the task of water resource management directly challenges the state, either by mobilizing popular opposition to pollution and dam-building, or by frustrating its unitary, hierarchical governance. Several scholars highlight the potential for water resource issues to mobilize protest and activism, even in the midst of China's tightening authoritarianism. Notably, civic and non-governmental activism has played a critical role in slowing or reversing several large dam projects, especially in south-western China. ${ }^{9}$ A smaller number of accounts emphasize the challenges that managing water resources pose for central-local and inter-jurisdictional relations in China. ${ }^{10}$ Perhaps the most memorable of these is David Lampton's quip that "Water, because it crosses

2 Deng and Yang 2013.

3 Important descriptive accounts include Liu, Changming 1998; Nickum 1998; Li, Wei, Beresford and Song 2011.

4 Chi 1963.

5 Wittfogel 1957.

6 See Cheung 2014; Moore 2014b; Crow-Miller 2015.

7 Habich 2016; Crow-Miller, Webber and Rogers 2017.

8 Notable treatments include Shapiro 2002; Pietz 2015; Zhang, Ling 2016.

9 See Economy 2004; Mertha 2008; Tilt 2014.

10 Lieberthal and Oksenberg 1988; Huang and Xu 2017; Wang, Raymond Yu, et al. 2017. 
administrative boundaries, forces different organizations and administrative units to do what they most abhor - deal with each other."11

Unsurprisingly, these accounts employ a wide range of theoretical frameworks, and their divergence does little to aid the cause of gaining a better understanding of the broad relationship between water and politics in modern China. Theories like political ecology, which emphasizes the ways in which environmental change and degradation reflect elite attempts to control and distribute valuable natural resources, and governmentality, which probes the many ways in which states and governments attempt to control populations and landscapes, find considerable purchase among scholars seeking to explain the consequences of China's rampant hydraulic engineering. ${ }^{12}$ But this structural focus obscures the profound difficulties central policymakers face in achieving their objectives because of the complexities of water governance and management at the local level, including outright opposition and non-compliance with centrally formulated policies. ${ }^{13}$ Scholars concerned with these dimensions of Chinese water politics apply social movement theory and the well-established model of fragmented authoritarianism to explain why water management issues challenge, and perhaps even threaten, the authority and legitimacy of the Chinese state. ${ }^{14}$ Yet these theories, too, appear strained to explain the limited role that non-governmental and private sector actors play in water governance, as well as the state's considerable success in tackling issues like flood control. ${ }^{15}$ How, then, should we understand these divergent characterizations of the relationship between water and politics in contemporary China?

In the remainder of this article, I suggest that the key to solving this puzzle is to see each of these themes as different dimensions of a complex relationship between water, politics and governance that has markedly evolved over the history of the People's Republic of China (PRC). Viewed in this historical perspective, it is clear that water both shapes and reflects politics and governance in contemporary China. The hydraulic engineering works of the PRC have bolstered its legitimacy and underpinned its break-neck development. Yet, in a striking paradox, the very scale of these herculean state-building and developmental objectives has continually required the Chinese state to reform itself to meet the demands of flood control, water supply and now pollution and ecosystem protection. And, while in this way water has shaped China's governance and its politics, one can also see in it the reflection of the state's broader struggle to build a fully functional, modern state.

11 Lampton 1987, 157.

12 Rogers et al. 2016; Webber, Crow-Miller and Rogers 2017; Rogers and Crow-Miller 2017.

13 Clarke-Sather 2012; Moore 2014a; Pia 2017. Clarke-Sather stresses how state-backed agricultural development efforts fundamentally complicate the relationship between water users and resources, while Pia highlights the ethical dilemmas faced by local officials in implementing market-driven policies.

14 Lieberthal 1992. Webber and Han (2017) update fragmented authoritarianism to account for new nonstate and transnational actors.

15 See Moore 2018. 
By examining a wide range of documentary sources, this article surveys the evolution of water policy and politics in China from 1949 to the present. On the basis of this historical analysis, I divide the history of Chinese water policy and politics under the PRC into three distinct periods, each of which reflects the state's broader political and economic objectives of the time. These periods are therefore distinguished in several ways: politicization and state-building from 1949 to 1977, characterized by small-scale irrigation and flood control based on mass labour mobilization; plumbing China's major river systems in the service of economic development from 1978 to 1997, defined by construction of large-scale flood control, wastewater treatment and water-supply infrastructure; and finally pluralizing water resource management to address new environmental challenges and non-governmental actors, from approximately 1998 to the present. These periods are, however, not sharply delineated, and are cumulative rather than successive: state-building remains a crucial factor in present-day water politics, for example. However, the utility of distinguishing these periods is suggested by a content analysis of the historical coverage of major Chinese newspapers, which identified three major periods: one lasting from 1946 through the 1980s, in which discussion of flooding and drought dominated; a second lasting from the late 1980s to the late 1990s which is characterized by a fixation on economic growth; and finally a recent period in which environmental issues became paramount. ${ }^{16}$

The definition of these historical periods moreover helps to highlight three durable characteristics of Chinese water policy and politics over time. The first, and perhaps most important, is its strategic significance for senior officials. While the interest of China's leadership in water resources is long-standing, in 2011 water became for the first time a focus of the Chinese Communist Party Central Committee No. 1 Policy Document, and other official statements at the time noted the significance of water scarcity as a "national security" issue. ${ }^{17}$ Second, despite this significance, water policy has been shaped by a fundamental tension between policy approaches, such as administrative and market-based measures and modalities, including state regulation versus public participation. ${ }^{18}$ Such tensions signal the significance of a third defining feature of Chinese water policy and politics, namely coordination problems between levels of government, the public and private sectors, and neighbouring jurisdictions. Bureaucratic conflict is endemic, especially with respect to large infrastructure projects. Zhou Enlai's 周恩来 observation that the Ministry of Water Resources (MWR), theoretically the lead agency for all water resource issues, "keeps getting knocked down and getting back up" (lübai lüzhan 屡败屡战) in conflicts with other bureaucracies, remains incisive. ${ }^{19}$ As the following sections illustrate, this historical

19 Wang, Weiluo 1999. 
context is essential to understanding how water both shapes and reflects politics and governance in contemporary China.

\section{Politicization and State-building, 1949-1977}

The first and most fundamental aspect of Chinese water politics is the critical role played by water conservancy in strengthening the legitimacy of the PRC during its early years. During this period, the state sought to re-shape China's hydrology as a symbol of the New China. This importance was reflected in a series of highprofile work conferences convened by Party leaders soon after taking power. In 1949, Premier Zhou Enlai proclaimed to delegates at one such conference that "to enrich the nation and benefit the people, we must start constructing water conservation works." 20 This conference was followed by a second the following year that proposed a nationwide programme of water works, including dams, reservoirs and canals. The key role that water resource development played in legitimizing the new government is illustrated by the fact that following the Korean War, cadres were exhorted to re-double their efforts to promote water conservancy as a means of "bringing peace and stability to the country" (anbang dingguo 安邦定国). ${ }^{21}$ A Yellow River Conservancy Commission (YRCC) history leaves little doubt as to the scale of the state's hydraulic ambitions during this period: "In short, we wanted to conquer the Yellow [River], and transform the Yellow [River] basin's natural condition ... in order to satisfy with Yellow River resources the demands of socialist construction and the coming communist transformation of the national economy." 22

China's post-1949 leaders tied their legitimacy closely to the control of flooding, historically one of China's most deadly natural hazards. This was seen as especially important in parts of the Yellow River (Huanghe 黄河) basin: “The lower reaches of the Yellow became some of the most politically important liberated areas for the Party." ${ }^{23}$ A 1955 publication further proclaimed that "With the coming of People's Democracy, a remarkable change has been brought about in the lower reaches. A stubborn fight against the calamities caused by the river has been waged by the masses under the leadership of the Chinese Communist Party and the People's Government." 24 Indeed, as such proclamations suggest, the state intended to rely on large-scale mobilization of peasant labour to build the necessary water works, which the same publication observed would require "all-round cooperation between government and people." 25

The struggle to control flooding quickly became the chief priority of water policy in early Communist-era China. A 1955 edition of Renmin ribao 人民日报 set

20 MWR and YRCC 2006, 82.

21 YRCC Yellow River History Editorial Office 1986, 82-85.

22 YRCC 1991, 121.

23 YRCC Yellow River History Editorial Office 1986, 2-3.

24 Teng 1955, 14.

25 Ibid., 24-28. 
the tone by pledging to "struggle" and "spare no effort" to control flooding along the Yellow River. ${ }^{26}$ The priority accorded to water policy, and particularly flood control, is also reflected in the re-organization of administration at both central and local levels. Authority for flood control and other water resource management tasks in the Yellow River and Yangtze River (Changjiang 长江) basins was atypically ceded by line ministries to special regional authorities known as the Yellow River Conservancy Commission and Yangtze River Planning Office, respectively. ${ }^{27}$ The State Council, meanwhile, established a separate National Flood Control Headquarters with branches in each province to directly manage flood emergencies. ${ }^{28}$ Local governments, too, adopted special administrative arrangements to reflect water policy priorities. By 1955, every riparian county and township in Shandong had established a dyke protection committee (hudi weiyuanhui 护堤委员会) and, in an indication of their importance, county-level committees were chaired by the second-highest ranking official in the county. ${ }^{29}$

But while its flood control efforts demonstrated both the determination of the PRC to eliminate one of China's longest-standing natural hazards and its ability to capably mobilize peasant labour in the service of state-building, the Sanmenxia 三门峡 Dam controversy in the 1960s demonstrated the extent to which bureaucratic and ideological conflict could undermine its objectives. The dam was intended to simultaneously control flooding and siltation in the lower reaches of the Yellow River and enjoyed Mao's personal support and patronage. However, despite his exhortations to "play on the same team" (quanju yipanqi 全 局一盘棋), Mao's allies ignored the warnings of hydrologists and engineers. Consequently, the sedimentation rate was greatly underestimated, and within four years of commencing operation sediment filled half the reservoir, prompting the hydropower plant to be taken out of operation. ${ }^{30}$ Because of the dam's high profile, the challenge was raised to senior levels, and in 1964 Zhou and the State Council convened a special meeting on the Sanmenxia problem. The tensions of the Cultural Revolution period were in full display at the meeting: water resource engineers, who adamantly argued that the problem would only be solved through extensive erosion control efforts, were pitted against ideologues, who supported the construction of additional sluice gates as it promised a quicker fix. ${ }^{31}$

The controversy was eventually resolved through a compromise policy known as “storing clean water and draining the muddy" (xuqing paihun 蓄清排浑): during winter, when sediment loads were low, Sanmenxia's gates would be opened only during high-flow periods, alleviating pressure on the dam. However, the

26 "Henan, Gansu, Shaanxi, Beijing, dengdi gejie renmin rilie huanying genzhi he kaifa Huanghe" (All the people in Henan, Gansu, Shaanxi, Beijing, etc. warmly welcome control and development of the Yellow River). Renmin ribao, 24 July 1955, 1.

27 US Joint Publications Research Service 1965, 155.

28 Greer 1979, 75; YRCC Yellow River History Editorial Office 1986, 87.

29 YRCC 1995, 346.

30 Yellow River Sanmenxia Water Conservancy Project Editorial Committee 1993, 79; Wang, Weiluo 2002, 90.

31 YRCC 1991, 161-62. 
compromise proved unsatisfactory as it failed to address the underlying problem of soil erosion. In the meantime, increased water demand and competition between the provinces began to strain the central state's ability to increase water supplies to thirsty northern cities. ${ }^{32}$ By the mid-1970s, as a result of these growing pressures, diversions began to be put in place in the lower reaches to provide drought relief in the North China plain, and particularly to aid urban water users in Tianjin municipality. ${ }^{33}$ From 1972 to 1973, the State Council ordered the diversion of some 1.6 million cubic metres of water from Henan to Tianjin, stoking discontent in poorer Henan. ${ }^{34}$ These new demands and tensions set the stage for the second phase of water resource policy and politics in modern China, one most accurately referred to as developmental.

\section{Plumbing the State for Growth and Development, 1978-1997}

Despite Party leaders' efforts to demonstrate their legitimacy through flood control and other water works, water resource management under the PRC has also always been motivated by a less ideological developmental mission. This developmental aspect of water policy in the early years of the PRC is well illustrated by the comprehensive development plans issued after the mid-1950s for each of the country's major river basins. These plans were aimed at promoting regional economic development, often through the construction of multi-purpose dams such as Sanmenxia that would provide water storage, hydropower production and flood control. ${ }^{35}$ Perhaps the best example was a 1954 report, commissioned by the State Planning Commission, on the comprehensive development of the Yellow River. The report proposed the construction of 46 dams along the whole length of the river for flood and erosion control, irrigation and hydropower development. A second, related focus of such plans was the development of large irrigation districts to support the expansion of collective agriculture. ${ }^{36}$ Throughout the Cultural Revolution period, however, the developmental aspect of water policy was obscured by its ideological, nation-building dimension.

Only with the end of the Cultural Revolution and the beginning of the reform period did the developmental mission gain precedence, largely as a result of increased water demand and flood risk in China's more densely populated areas. Although the construction of dams like Sanmenxia had alleviated China's historical flood risk, a major 1982 flood event in the Yellow River reinforced the need to further develop flood-control infrastructure to protect the centres of China's nascent economic reforms. ${ }^{37}$ Water scarcity also become a major success). Renmin ribao, 20 December 1974.

33 Ibid.

34 YRCC Yellow River History Editorial Office 1986, 263.

35 US Joint Publications Research Service 1965.

36 Cheng 2008.

37 YRCC Yellow River History Editorial Office 1986, 277. 
concern for China's economic planners during this period. In 1981, diversions from the Yellow River to Tianjin had to be suspended owing to drought conditions. ${ }^{38}$ Throughout the 1980s, water use grew with astonishing speed (see Figure 1), particularly for municipal use. ${ }^{39}$ By the end of the decade, continuing water shortages for Tianjin and other urban areas in the north-east led the MWR to entrust the Shandong government with investigating water transfer schemes to meet this added demand. ${ }^{40}$ This move presaged a shift from a reliance on mass mobilization, so prevalent during the state-building period, towards large-scale water diversions and the contentious politics of coordination and allocation that they entail.

The approach of the central government to managing China's water resources during the developmental period was notably collaborative. In contrast to the nation-building period of water governance in China, which relied principally on mass labour and individual prestige projects like the Sanmenxia Dam, the developmental period returned to an emphasis on integrated and collaborative development. Stressing the “intimate relation” (jinmi guanxi 紧密关系) of water use in different parts of the basin, the MWR and the YRCC initiated an ambitious effort to revise earlier inter-provincial water resource allocations to reflect new economic realities. ${ }^{41}$ Accordingly, in the Yellow River basin the YRCC engaged provincial governments in extensive consultations regarding present and future water demands, attempting to account for factors such as Shanxi's future demand for water for coal extraction and processing. ${ }^{42}$ This approach set the stage for a regional approach to water policy and water resource management, in which attempts were made to balance the demands of different provinces and economic sectors.

The best example of this regional, developmental approach is the Yellow River Quantity Allocation Plan, which was approved by the State Council in 1987 and replaced an earlier, 1950s era development plan for the basin. Unlike earlier policies, the Allocation Plan envisioned a strategic allocation of water among provinces according to anticipated future water needs as a result of planned economic development. These needs were assessed through intensive consultations with provincial-level officials; however, they focused almost entirely on economic development and ignored environmental water requirements. Initial discussions on an inter-provincial allocation took place at a 1984 conference of all Yellow River basin provinces at which it was intended to produce a plan to "fully utilize" the Yellow River's flows. Employing common practice for important policy issues, the MWR established a "leading group" to produce a report based on these consultations. This report would form the basis for an initial plan. Revisions were discussed at a major conference in 1988, and only after

38 "Beishui zhiwo" (Background to my water). Renmin ribao, 10 September 1983, 2.

39 UN Food and Agriculture Organization 2016.

40 YRCC Yellow River History Editorial Office 1986, 359.

41 Ibid., 300.

42 Li, Dong 2010. 


\section{Figure 1: Increasing Water Use in China during the Reform Period}

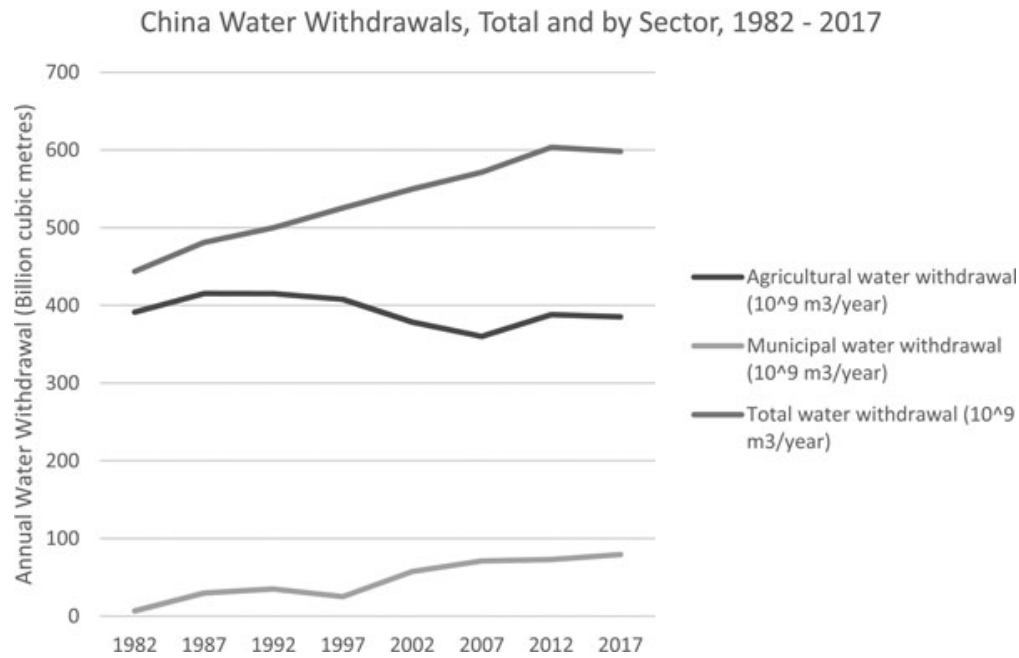

obtaining the agreement of provincial officials that the plan was "basically correct" were implementing instructions for the Allocation Plan issued. ${ }^{43}$

Despite the emphasis on consultation in plan formulation, the developmental period was characterized above all by large-scale infrastructure construction. After 1978, construction of large dams more than 150 metres in height accelerated rapidly (see Figure 2). ${ }^{44}$ The best example of China's reliance on large-scale infrastructure during the developmental period, however, is the "south-north water transfer project" (SNWTP). Planning for long-distance, inter-basin water transfers began as early as 1959 when a workshop to examine its feasibility was convened in Beijing with representatives from the YRCC and several provincial governments. ${ }^{45}$ The project was finally endorsed at the 1978 Party Conference, when a decision was made approving in principle a plan to construct three separate water-diversion channels, termed the eastern, central and western routes, which would together compensate for the growing pressures on the Yellow River basin and other northern water resources by providing water security for agriculture, industry and urban use throughout the north. ${ }^{46}$ The influence of the developmental mission in this decision was indicated by the additional decision to give priority to the eastern route, which was to be constructed first as a means of addressing chronic water shortages in the lower Yellow River basin. Traces of the older nation-building mission in Chinese water policy were clearly evident in the discussion; representatives at the 1978 Party Congress

43 YRCC Yellow River History Editorial Office 1986, 298-99.

44 Chinese National Commission on Large Dams 2010. Figure depicts list of China's 20 highest dams according to the Commission.

45 "Nanshui beidiao chuiqi qianzouqu" (Prelude to the south-north water transfer project). Renmin ribao, 1 March 1959, 2.

46 Moore 2014b. 


\section{Figure 2: Growth in China's Water Infrastructure during the Reform Period}

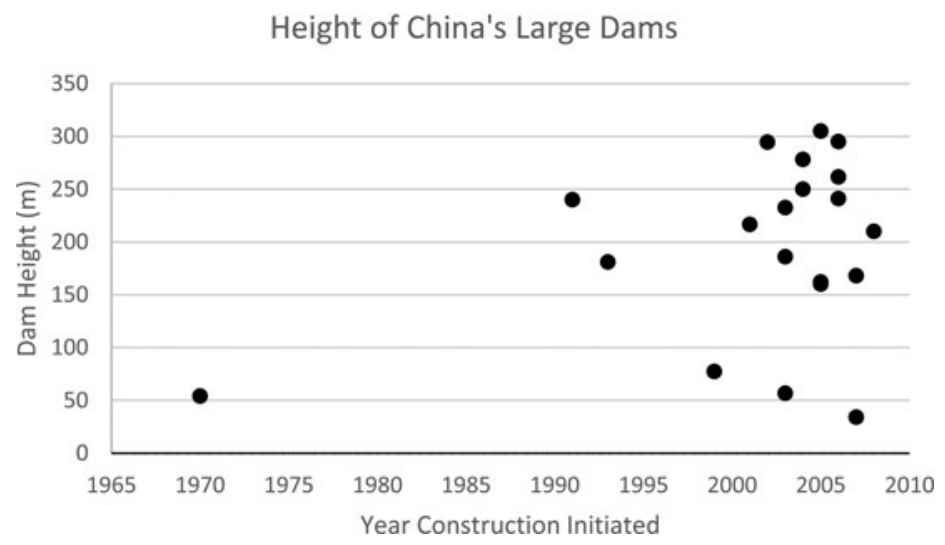

noted with satisfaction that the eastern route would rejuvenate parts of the ancient Grand Canal, which had historically linked northern and southern China. ${ }^{47}$

Large-scale water infrastructure construction after 1978 was critical to China's economic development. However, the emphasis of water resource policy on infrastructure during the period did little to address more complex management challenges, such as pollution or the maintenance of minimum streamflow, which became increasingly prevalent towards the end of the 20th century. These challenges were visibly illustrated by the desiccation of the lower Yellow River, which by the late 1990 s rarely reached the sea, a fact that attracted significant international media coverage and became a source of considerable embarrassment to the Chinese government. ${ }^{48}$ The government's policy response to this challenge moreover signalled a shift from the collaborative process embodied in the 1987 Yellow River Water Quantity Allocation Plan. Instead of following the model of inter-provincial consultation, the central government's Yellow River Framework Plan for Administration and Development, issued in 1997, established a framework of strict central control, stressing "overall control" and "strict supervision" of local officials and enterprises. ${ }^{49}$ This centralized regulatory approach was subsequently strengthened through a process introduced in 1998 whereby provincial governments were required to submit water withdrawal plans in advance for approval by the YRCC and MWR. ${ }^{50}$ In the third and most recent phase of water policy under the PRC, this centralized approach would be greatly tested by the demands of addressing the country's worsening water pollution.

47 Hua 1978; "Yao ba nanshui beidiao guihua gaohao" (On the need for sound planning of the southnorth water transfer project). Renmin ribao, 21 April 1979, 3.

48 MWR 1999.

49 E 1999.

50 National Development and Reform Commission and MWR 1998. 


\section{Pluralization and Ecological Crisis, 1998-Present}

The emergence of water quality issues signalled the nascent beginnings of the third and most recent period in Chinese water policy and politics, which is distinguished by several characteristics. First, water policy since 1998 has sought to balance human and environmental water needs and also to incorporate, to a limited degree, the interests of non-governmental and state actors. Second, during the ecological period the government has relied increasingly on legislation to achieve its water policy objectives, even as it has continued to execute large-scale water infrastructure projects like the SNWTP. Third, and perhaps most significantly, Chinese water policy during the ecological period has been informed by a sense of almost existential risk; perhaps no statement better defines it than the 1998 warning, attributed to Premier Wen Jiabao 温家宝, that the “survival of the Chinese nation is threatened by the country's shortage of water." 51 This sense of importance has ensured that while tentative steps have been taken to increase the role of non-governmental actors in water resource management, the state remains in firm overall control.

Despite these distinctive characteristics, the roots of the recent emphasis on environmental issues lie firmly embedded in the developmental period. While water quantity issues, particularly flooding and regional shortages, dominated the developmental period of Chinese water policy, water quality issues also began to emerge as a significant challenge for local authorities. As early as 1972, the Henan Provincial Health Bureau established a group responsible for pollution control, and in 1978, it established a water-quality monitoring centre. These putative environmental protection bureaucracies were gradually empowered with the ability to administer orders to prevent pollution, install pollution control technologies and to institute financial penalties for non-compliance. ${ }^{52} \mathrm{With}$ passage of the Water Pollution Control Law in 1984, by the late 1990s pollution control absorbed most of the energies of local water resource bureaus, particularly in the more developed parts of China. ${ }^{53}$ Urban areas like Xi'an and Lanzhou experienced particularly rapid growth during this period, creating large clusters of highly polluting industries. In the Lanzhou stretch of the river alone, some 500 million tons of pollutants were released annually by the early 2000 s. ${ }^{54}$ Crucially, however, the decentralized nature of Chinese water governance offered few mechanisms to address water pollution across jurisdictional boundaries. ${ }^{55}$

Such challenges made it increasingly apparent that Chinese water policy had to move beyond the emphasis on infrastructure and regulation that characterized the developmental period. Beginning in the 1990s, this realization led the government to undertake significant reforms to the 1988 Water Law, which hitherto had

51 Pflaker 2005.

52 YRCC Yellow River History Editorial Office 1986, 325-27.

53 Li, Guangchun 1999, 55.

54 Dou 2004.

55 Shaanxi Government 2000, 16. 
formed the basis of China's water policy. ${ }^{56}$ While the 1988 law had sought to lay a foundation for water use regulation and allocation and water project construction, revisions embodied in the 2002 law sought to promulgate a far more comprehensive legislative framework that would fulfil environmental protection goals as well as water resource management objectives. Table 1 summarizes several of the most notable differences between the 1988 and 2002 laws, including new provisions to protect aquatic ecosystems, strengthen enforcement and account for environmental water requirements. ${ }^{57}$

But while defined in large part by this new legislation, the ecological period has also been shaped by a growing role for market mechanisms in allocating water among different users. Indeed, market mechanisms form the core of the government's attempts to create a "water-saving society." 58 In urban areas, the Chinese government has adopted a tiered pricing structure, which will increase the direct cost of water for many users in an attempt to spur greater conservation, while in agricultural regions the government has instead established water markets in which the rights to use a set quantity of water under an overall cap are distributed to irrigation districts and water user associations, who can then buy and sell their water rights. During the summer of 2014, Beijing appeared to double-down on the use of a market-based approach by announcing that pilot water rights trading systems would be established in seven provinces, including Ningxia, Inner Mongolia and Gansu. ${ }^{59}$

The government's enthusiasm for implementing these market-oriented reforms has subsequently been dampened by a number of acute challenges. First, water pollution in many parts of the country approaches crisis levels. According to the most recent data available from the MWR, about one-third of China's waterways remain unfit even for indirect human uses like irrigation. ${ }^{60}$ Second, a growing number of inter-jurisdictional disputes, particularly over pollution, have seriously challenged China's water governance system, in some cases requiring emergency State Council intervention. ${ }^{61}$ Third and finally, several well-publicized incidents, such as the 2005 Songhua River 松花江 benzene spill and severe water quality problems associated with the SNWTP, undermined public confidence in China's water quality standards. ${ }^{62}$ To combat the sense of crisis, China has in recent years adopted one of the world's most ambitious regulatory frameworks for water. Formally referred to as the "most stringent water resource management system” (zuiyange shuiziyuan guanli zhidu 最严格水资源管理制度), the policy is also known as the "three red lines" (santiao hongxian 三条红线) in reference to its three chief objectives, namely, strictly controlling total water use,

\footnotetext{
56 Wouters et al 2004.

57 NPC 1988; 2002.

58 Xia and Pahl-Wostl 2012.

59 Moore 2015.

60 MWR 2014.

61 Li, Hao, Liu and Huang 2010; Moore 2014a.

62 Moore 2014b.
} 


\section{Table 1: Summary of Differences between 1988 and 2002 Water Laws}

\begin{tabular}{|c|c|c|}
\hline Provision & 1988 Version & 2002 Version \\
\hline $\begin{array}{l}\text { Basin-wide } \\
\text { planning }\end{array}$ & $\begin{array}{l}\text { Formulated by central } \\
\text { government in conjunction } \\
\text { with local governments }\end{array}$ & $\begin{array}{l}\text { Formulated by designated river basin } \\
\text { authorities in consultation with local } \\
\text { governments; functional zoning plans } \\
\text { to be developed that assess pollution } \\
\text { load capacity, protect drinking water } \\
\text { sources }\end{array}$ \\
\hline $\begin{array}{l}\text { Water use } \\
\text { entitlements }\end{array}$ & $\begin{array}{l}\text { Water use according to permits } \\
\text { issued by government }\end{array}$ & $\begin{array}{l}\text { Water use must meet beneficial use } \\
\text { criterion; water use requires both a } \\
\text { licence and payment of fees based on } \\
\text { quantity of water abstracted }\end{array}$ \\
\hline $\begin{array}{l}\text { Principles of } \\
\text { water use }\end{array}$ & $\begin{array}{l}\text { Emphasizes economy and } \\
\text { conservation }\end{array}$ & $\begin{array}{l}\text { Directs the government to use } \\
\text { technologies to increase use of recycled } \\
\text { and reclaimed water; increase water use } \\
\text { efficiency }\end{array}$ \\
\hline $\begin{array}{l}\text { Environmental } \\
\text { water } \\
\text { requirements }\end{array}$ & $\begin{array}{l}\text { No large cities or water-intensive } \\
\text { industries to be developed in } \\
\text { water-scarce areas }\end{array}$ & $\begin{array}{l}\text { Give full consideration to "environmental } \\
\text { needs of water in ecosystems"; establish } \\
\text { proper arrangements for "maintaining } \\
\text { proper flow to maintain natural } \\
\text { purification capability" }\end{array}$ \\
\hline $\begin{array}{l}\text { Environmental } \\
\text { impact } \\
\text { mitigation }\end{array}$ & $\begin{array}{l}\text { Water project construction } \\
\text { should minimize effects on } \\
\text { local and downstream areas; } \\
\text { projects that negatively impact } \\
\text { fisheries must adopt } \\
\text { "remediation" measures }\end{array}$ & $\begin{array}{l}\text { Proper arrangements must be made for } \\
\text { "protection of aquatic life" }\end{array}$ \\
\hline $\begin{array}{l}\text { Dispute } \\
\quad \text { resolution }\end{array}$ & General provisions only & $\begin{array}{l}\text { Specific processes and protocols for } \\
\text { handling disputes; establishment of } \\
\text { evidentiary standards; designation of } \\
\text { specific punishments for officials who } \\
\text { neglect duty to resolve disputes as well } \\
\text { as parties who "stir up unrest," "engage } \\
\text { in gang fighting," etc. }\end{array}$ \\
\hline Enforcement & $\begin{array}{l}\text { Provision for fines and criminal } \\
\text { prosecution }\end{array}$ & $\begin{array}{l}\text { Statutory fines with minimums of } 10- \\
50,000 \text { yuan; maximums of } 50-100,000 \\
\text { yuan depending on infraction; } \\
\text { provision for local water authorities to } \\
\text { collect surcharge on overdue water } \\
\text { permit fees }\end{array}$ \\
\hline
\end{tabular}

establishing water use efficiency standards and preventing water waste, and finally establishing nationwide water quality standards and more stringently controlling effluents entering waterways. ${ }^{63}$ First mentioned in the Chinese Communist Party Central Committee's No. 1 Policy Document of 2011, the policy was formally promulgated in State Council Opinion No. 3 in 2012, which further quantified the "three red lines." 64 
China's "three red lines" policy (TRL hereafter) is distinguished from other elements of the country's water resource policy by three main characteristics, all of which also characterize the ecological period in Chinese water policy. First, the TRL is a command-and-control regulatory policy rather than a marketbased mechanism. Second, the TRL aims to set a comprehensive water policy by addressing quantity, quality and efficiency issues together. Third and most significantly, the TRL reflects a sense of ambition to match the perceived severity of China's water challenges. The TRL policy itself consists of three standards, all set to be met by 2030 . First, total national water consumption will be capped at a level less than China's total renewable freshwater reserves, a figure corresponding to less than 700 billion cubic metres annually. By comparison, in 2011 China consumed about 600 billion cubic metres, a figure representing about 75 per cent of its total renewable freshwater resources. Second, 95 per cent of major waterways will meet water quality standards, which will also be made more stringent. ${ }^{65}$ Third, China's water productivity will be enhanced to less than 40 cubic metres per 10,000 yuan of economic value-added - a level approximating the developedcountry average - and the country's average irrigated water utilization rate will be raised to 60 per cent. ${ }^{66}$ This represents a substantial increase from the current rate of 30-40 per cent, but is still far less than the developed country average of 80-90 per cent. ${ }^{67}$ Together, these elements of the TRL make it one of the world's most ambitious water policy initiatives. Indeed, as an MWR official put it, "There are no other countries that have set such detailed targets to restrict their own development by limiting usage of water resources." 68

However, the very ambition of the TRL raises basic questions concerning its feasibility, and whether in the ecological period of Chinese water policy it can achieve its objectives. So far, the government has signalled its determination to fully implement the TRL policy through both pilot schemes and phased implementation at local levels. In 2014, the city government of Kunming became one of the first local governments to adopt the policy when it announced that it would limit annual water consumption to 257 million cubic metres by 2015 , and 370 million cubic metres by 2030 , as well as increase water quality compliance of designated waterways to 65 per cent, with some key drinking water areas reaching 95 per cent compliance. ${ }^{69}$ Similarly, the city government of Guang'an 广安 in Sichuan issued regulations to reduce water use intensity by 31 per cent relative to 2010 levels, raise irrigation efficiency to at least 44 per cent, and limit total water use to 99 million cubic metres by 2020 before finally reaching a maximum of 120 million cubic metres in 2030.70 This phased

65 "Water usage to be monitored better." China Daily, 8 May 2012, http://www.china.org.cn/environment/ 2012-05/08/content_25332381.htm. Accessed 23 April 2014.

66 State Council 2012.

67 Zhang, Guang Xia, and Deng 2002.

$68 \mathrm{Wu} 2012$.

69 Du 2014.

70 Liu, Xiaoyong 2014. 
implementation of the TRL has continued rapidly. In March 2014, the viceminister for water resources, Jiao Yong 矫勇, announced that the government would soon issue water quantity allocations for all remaining provinces. Jiao also reported that about 95 per cent of prefecture-level jurisdictions and about 700 of China's counties had been assigned water quantity quotas under the TRL. ${ }^{71}$ The state's seeming preference for an administrative control approach to meeting the water policy challenges of the ecological era are also indicated by the 2016 launch of the "river chief" (hezhang 河长) system, which makes cadres responsible for inter-jurisdictional water issues like pollution control. ${ }^{72}$

The hierarchical approach of the TRL and "river chief" systems moreover contrasts sharply with another feature of the most recent period in Chinese water policy, namely, the gradual emergence of NGOs. Such actors, usually in the form of local civic movements, had first exercised a visible role by mounting effective opposition to several dam construction projects during the 1990 s and 2000 s. $^{73}$ NGO input was critical to informing several aspects of water policy during the developmental and ecological period, including the design of water rights trading systems and the drafting of the 2002 Water Law. ${ }^{74}$ However, in recent years the role of NGOs in Chinese water policy and politics has received a significant boost. First, revisions to China's Environmental Protection Law, which took effect in 2015, carved out a statutory role for citizens to "participate in and supervise" environmental enforcement, and for NGOs to bring lawsuits for environmental harms. ${ }^{75}$ Since then, NGOs have sued several large enterprises, although the overall record of success remains mixed. ${ }^{76}$ Second, NGO activists secured a major victory for conservation in late 2016 when the Chinese government abandoned plans to dam China's last free-flowing river following a prolonged campaign. ${ }^{77}$ However, it remains too soon to say whether greater engagement of NGO actors will definitively mark the ecological period in Chinese water policy and politics, or whether like preceding eras it will be dominated by the state.

\section{Conclusion}

Water has consistently shaped China's politics and governance, especially in terms of institutional organization, but it also reflects broader issues in its political economy. The preceding historical survey has revealed three consistent features of water policy and politics in China over time. First, water issues have

71 "Shuili bu: shuili 'santiao hongxian' zhibiao tixi jiben jianli" (Ministry of Water Resources: water conservancy "three red lines" target system established). Diyi caijing, available through Zhongshi wang, 21 March 2014, http://www.cs.com.cn/xwzx/ms/201403/t20140321_4341079.html. Accessed 9 October 2014.

72 Much about this system remains unclear, but it is potentially transformative. See Chien and Hong 2018.

73 Mertha and Lowry 2006; Mertha 2008.

74 Liu, Bin, and Speed 2010.

75 NPC 2014.

76 Bourdeau and Schulson 2016.

77 Phillips 2016. 
often been high on the agenda of senior leaders, who have consistently seen the assurance of water availability and protection from flooding and drought as an important source of legitimacy. More recently, senior officials have added water pollution control to this list. Second, China's water policy rather discordantly combines infrastructure solutions, regulation and market-based mechanisms. Here, the struggle of the state to adapt to the demands of a rapidly modernizing and diversifying society comes into sharp relief. The challenges of environmental protection, non-governmental stakeholder proliferation and private sector involvement have forced a partial pluralization of water resource management. Yet a third and final conclusion is that while the nature of state involvement in Chinese water policy and politics has changed over time, the dominant role of the state has remained a constant. State involvement in the water sector has become more formalized and increasingly relies on legislative and regulatory authority. But the formalization of the state's role should not be confused for diminution; instead, it reflects an attempt at maintaining pre-eminence. The putative influence of NGO actors in China's water politics remains very much at the sufferance of the state.

Going forward, a number of questions remain that the nascent literature on water policy and politics in China can help to answer. First, is it possible that the creeping pluralization of China's water sector will eventually create a meaningful role for private companies and NGOs in policymaking, as is the case in other countries? Or, as the literature on authoritarian environmentalism suggests, ${ }^{78}$ will the state hold fast to its trump cards over an issue of profound political importance? Second, will China's ongoing economic reform strategy, and the market orientation on which it is premised, eventually preference marketbased water policy measures? Third, and perhaps of greatest long-term significance, is how will the politics of water scarcity and water pollution play in the wider dynamics of sustainable development and environmental public goods provision in China? While water scarcity and flood control have attracted high-level policy attention, it remains somewhat unclear how water policy agendas relate to those of other powerful bureaucratic actors, including those surrounding food and energy security. Similarly, for the public at large air pollution has, to date, attracted the greatest attention, but it is possible that water pollution may stoke even greater concern. Will Beijing approach these tensions in the same way it has for other environmental issues, that is, adopting serious policy reforms while seeking to defuse public discontent? ${ }^{79}$ Or will it adopt a different strategy?

These remain open questions, but it is hoped that the framework presented in this article can eventually help to answer them. By establishing a historical "baseline" for the evolution of Chinese water policy and politics, and proposing some key factors and objectives that have shaped them over time, this framework should at least offer a foundation for more systematic research. It also highlights 
the utility of developing a theoretically coherent sub-literature on Chinese water policy and politics. Indeed, up till now, water policy and politics have seemed to lurk in the background of Chinese political studies, periodically surfacing as a means of illustrating a key point about the country as a whole but never coalescing into a literature of their own. This inattention represents a serious lacuna, not only because water issues themselves are growing more serious for China in light of climate change, urbanization and economic development but also because the study of water opens an important window into China's distinctive political and economic system, in which the framework of a liberal market economy rests uncertainly on the foundations of a hierarchical authoritarian state. The study of Chinese political economy needs a literature on the policy and politics of water issues, not only for their own sake but also to gain new insights into this fundamental contradiction.

\section{Acknowledgements}

I would like to thank Yifei Li, Judith Shapiro and the participants in an International Studies Association 2017 Annual Meeting panel discussion on Chinese environmental politics for their comments on an earlier draft. I am also grateful for the comments of the anonymous reviewers. Research for this article was partly funded by the John L. Thornton China Center of the Brookings Institution, with funds from the Ford Foundation. Portions of the material cited in this article will be published in my forthcoming book, Subnational Hydropolitics: Conflict, Cooperation, and Institution-Building in Shared River Basins, and have been reproduced by permission of Oxford University Press (https://global.oup.com/ academic/product/subnational-hydropolitics-9780190864101?cc=us\&lang=en\&).

\section{Biographical notes}

Scott MOORE is currently a senior fellow at the University of Pennsylvania Kleinman Center for Energy Policy, where he specializes in climate change, water policy and politics.

\footnotetext{
摘要：与其他国家相比，水资源管理是中国政策和政治的一个重要方面, 但是现有的学术尝试来理解这种重要性分散在大量缺乏统一理论框架的分 文献中。本文试图通过从历史的角度来考察这种关系如何展开，以确定当 代中国水，政治和治理之间关系的共同主题和特征。它确定了长期形成中 国水资源政治和治理的三个基本目标: 合法性;经济发展;和环境可持续性。 这些目标虽然不完美, 但映射到中华人民共和国历史上的不同时期, 从而 突出了它们的发展过程。这些目标共同解释了当代中国的水资源政策和政 策。这种理解表明, 水既是形式, 也是中国政治的反映, 并且突出表明中 国水政策和政策需要一个理论上连贯的子文献。
}

关键词: 中国; 水; 水治理; 政治经济; 环境; 可持续性 


\section{References}

Ball, Philip. 2017. The Water Kingdom: A Secret History of China. Chicago: University of Chicago Press.

Beeson, Mark. 2010. "The coming of environmental authoritarianism." Environmental Politics 19(2), 276-294.

Bourdeau, Karl, and Dan Schulson. 2016. "Citizen suits' under China's revised Environmental Protection Law: a watershed moment in Chinese environmental litigation?" Beveridge \& Diamond, PC, 9 March, http://www.bdlaw.com/news-1863.html. Accessed 12 December 2016.

Cheng, Youwei. 2008. "Huanghe de lishi yanbian yu Henan de xingshuai" (Historical evolution of the Yellow River and the rise and fall of Henan). In Yuguo Niu (ed.), Huanghe yu Henan luntan wenji (Collected Works of the Forum on Henan and the Yellow River). Zhengzhou: Huanghe shuili chubanshe, 189-196.

Cheung, Siu-Keung. 2014. "Reunification through water and food: the other battle for lives and bodies in China's Hong Kong policy." The China Quarterly 199, 1012-32.

Chi, Chao-ting. 1963. Key Economic Areas in Chinese History as Revealed in the Development of Public Works for Water Control. New York: Paragon Books.

Chien, Shiuh-Shen, and Dong-Li Hong. 2018. "River leaders in China: party-state hierarchy and transboundary governance." Political Geography 62, 58-67.

Chinese National Commission on Large Dams. 2010. China's Highest Dams, 20 July, http://www. chincold.org.cn/dams/DamInformation/A2010index_1.htm. Accessed 10 December 2016.

Clarke-Sather, Afton. 2012. "State development and the rescaling of agricultural hydrosocial governance in semi-arid northwest China." Water Alternatives 5(1), 98-118.

Crow-Miller, Britt. 2015. "Discourses of deflection: the politics of framing China's south-north water transfer project." Water Alternatives 8, 173-192.

Crow-Miller, Britt, Michael Webber and Sarah Rogers. 2017. "The technopolitics of big infrastructure and the Chinese water machine." Water Alternatives 10(2), 233-249.

Deng, Yanhua, and Guobin Yang. 2013. "Pollution and protest in China: environmental mobilization in context." The China Quarterly 214, 321-336.

Dou, Xian. 2004. "Shei zai wuran Huanghe?" (Who's polluting the Yellow River?). Tianshan wang, http://www. Accessed 9 November 2018.

Du, Zhongying. 2014. “Kunming 'santiao hongxian' yanguan shuiziyuan” (Kunming's "three red lines" strictly control water resources). Yunnan xinhua wang, 1 September, http://yn.xinhuanet. com/newscenter/2014-09/01/c_133609850_3.htm. Accessed 9 October 2014.

E, Jingping. 1999. "Zhi Huanghe guihua xiuding de zongti shexiang" (General consideration on revision of the Yellow River control plan). Zhongguo shuili, 12 February, http://www.chinawater.net. cn/cwr_journal/199902/990207.html. Accessed 29 November 2012.

Economy, Elizabeth. 2004. The River Runs Black: The Environmental Challenge to China's Future. Ithaca, NY: Cornell University Press.

Fujian Province Water Affairs Bureau. 2011. "Jiedu zhongyang yihao wenjian: shuiziyuan guanli huading 'santiao hongxian"” (Understanding the central government's No. 1 Policy Document: the "three red lines" plan for water resource management). Fujian shuili xinxi wang, 29 March, http://www.fjwater.gov.cn/html/3/696/66923_2011323448.html. Accessed 9 October 2014.

Gilley, Bruce. 2012. "Authoritarian environmentalism and China's response to climate change." Environmental Politics 21(2), 287-307.

Greer, Charles. 1979. Water Management in the Yellow River Basin of China. Austin, TX: University of Texas Press.

Habich, Sabrina. 2016. "Reasons to dam: China's hydropower politics and its socio-environmental consequences." In Jean-Marc Blanchard and Kun-Chin Lin (eds.), Governance, Domestic Change, and Social Policy in China. London: Springer Nature, 103-127.

Hua, Guofeng. 1978. "Tuanjie qilai, wei jianshe shehuizhuyi de xiandaihua qiangguo er fendou" (Unify in order to construct the nation-building and struggle of modern socialism). Renmin ribao, 7 March, 1-6. 
Huang, Qidong, and Jiajun Xu. 2017. "Scales of power in water governance in China: examples from the Yangtze River basin.” Society \& Natural Resources 30(4), 421-435.

Jiangsu Province People's Government. 2012. "Jiangsu sheng renmin zhengfu guanyu shixing zuiyange shuiziyuan guanli zhidu de shishi yijian" (Opinion of the Jiangsu Province People's Government on implementing the most stringent water resource management system), 15 March, http://szy.mwr.gov.cn/zdgz/zygszyglzd/201406/t20140610_566884.html. Accessed 15 October 2014.

Lampton, David. 1987. "Water: challenge to a fragmented political system.” In David Lampton (ed.), Policy Implementation in Post-Mao China. Berkeley, CA: University of California Press, 157-189.

Li, Dong. 2010. "Guowuyuan Huanghe fenshui yu shuidiao fang'an” (State Council Yellow River water division and water transfer plan). Shui xinxi wang, 2 March, http://www.hwcc.gov.cn/pub/ hwcc/wwgj/bgqy/jjqk/201003/t20100302_314548.html. Accessed 5 April 2012.

Li, Guangchun. 1999. "Jiaqiang jinggong guanli gongzuo ba Huanghe de shiye banhao" (Strengthening operation and administration work to improve Yellow River undertakings). Gongzuo yanjiu, 54-56.

Li, Hao, Tao Liu and Wei Huang. 2010. "Kuajie shuiziyuan chongtu dongyin yu xietiao moshi yanjiu" (Research on the drivers and resolution modes of transboundary water resource disputes). Ziran ziyuan xuebao 25(5), 705-712, http://www.jnr.ac.cn/CN/10.11849/zrzyxb.2010.05.001. Accessed 8 November 2018.

Li, Wei, Melanie Beresford and Guojun Song. 2011. "Market failure or governmental failure? A study of China's water abstraction policies.” The China Quarterly 208, 951-969.

Lieberthal, Kenneth. 1992. "Introduction: the 'fragmented authoritarianism' model and its limitations." In Kenneth Lieberthal and David Lampton (eds.), Bureaucracy, Politics, and Decision-making in Post-Mao China. Berkeley, CA: University of California Press, 1-30.

Lieberthal, Kenneth, and Michel Oksenberg. 1988. Policy Making in China: Leaders, Structures and Processes. Princeton, NJ: Princeton University Press.

Liu, Bin, and Robert Speed. 2010. "Water resources management in the People's Republic of China." In Xuetao Sun, Robert Speed and Dajun Shen (eds.), Water Resources Management in the People's Republic of China. New York: Routledge, 5-20.

Liu, Changming. 1998. "Environmental issues and the south-north water transfer scheme." The China Quarterly 156, 899-910.

Liu, Xiaoyong. 2014. "Guang'an shi xiada shuiziyuan guanli 'santiao hongxian' kongzhi zhibiao" (Guang'an city stays within the "three red lines" control quota for water resource management). Sichuan shuili ting, 30 June, http://www.scwater.gov.cn/zhxw/8482.htm. Accessed 9 October 2014.

Mertha, Andrew. 2008. China's Water Warriors: Citizen Action and Policy Change. Ithaca, NY: Cornell University Press.

Mertha, Andrew, and William Lowry. 2006. "Unbuilt dams: seminal events and policy change in China, Australia, and the United States." Comparative Politics 39, 1-20.

Moore, Scott. 2014a. "Hydropolitics in China: the pursuit of localized preferences in a centralized system." The China Quarterly 219, 760-780.

Moore, Scott. 2014b. "Modernization, authoritarianism, and the environment: the politics of China's south-north water transfer project." Environmental Politics 23(6), 947-964.

Moore, Scott. 2014c. "Pollution without revolution: why China's environmental crisis won't bring down the regime." Foreign Affairs, 11 June, https://www.foreignaffairs.com/articles/china/ 2014-06-10/pollution-without-revolution. Accessed 8 November 2018.

Moore, Scott. 2015. "The development of water markets in China: progress, peril, and prospects." Water Policy 17, 253-267.

Moore, Scott. 2018. "The political economy of flood management reform in China." International Journal of Water Resources Development 34(4), 566-577.

MWR (Ministry of Water Resources). 1999. "Huanghe liyu guihua gaiyao" (Synopsis of Yellow River basin planning), http:/ghjh.mwr.gov.cn/lyxx/hhgh/200910/t20091028_30058.html. Accessed 29 November 2012. 
MWR. 2014. 2014 Statistic Bulletin on China Water Activities. Beijing: Zhongguo shuili shuidian chubanshe.

MWR and YRCC. 2006. Renmin zhili Huanghe lishinian (Sixty Years of the People Controlling the Yellow River). Zhengzhou: Huanghe shuili chubanshe.

National Development Planning Commission and MWR. 1998. "Huanghe kegong shuiliang niandu fenpei ji ganliu shuiliang diaodu fang'an" (Yellow River annual water quantity usage allocation and drought water quantity adjustment plan), http://www.sxhh.gov.cn/zcfg/xzfg/200808/154.html. Accessed 7 November 2012.

Nickum, James. 1998. "Is China living on the water margin?” The China Quarterly 156, 880-898.

Nickum, James, Shaofeng Jia and Scott Moore. 2017. "The three red lines and China's water resource management policy in the twenty-first century." In Eva Sternfeld (ed.), Routledge Handbook on China's Environmental Policy. Abingdon: Earthscan, 71-82.

NPC (National People's Congress). 1988. "Water Law of the People's Republic of China." UN Food and Agriculture Organization Waterlex Database, 21 January, http://faolex.fao.org/docs/pdf/ chn1317E.pdf. Accessed 12 December 2016.

NPC. 2002. "Water Law of the People's Republic of China," 29 August, http://www.mwr.gov.cn/ english/laws.html. Accessed 12 December 2016.

NPC. 2014. "Environmental Protection Law of the People's Republic of China." China Dialogue, 24 April, https://www.chinadialogue.net/Environmental-Protection-Law-2014-eversion.pdf. Accessed 12 December 2016.

Pflaker, Ted. 2005. "China, parched and polluted, puts a price on water." The New York Times, 16 December.

Phillips, Tom. 2016. "Joy as China shelves plans to dam 'angry river'." The Guardian, 2 December, https://www.theguardian.com/world/2016/dec/02/joy-as-china-shelves-plans-to-dam-angry-river.

Accessed 12 December 2016.

Pia, Andrea. 2017. "Back on the water margin: the ethical fixes of sustainable water provisions in rural China." Journal of the Royal Anthropological Institute 23(1), 120-136.

Pietz, David. 2015. The Yellow River: The Problem of Water in Modern China. Cambridge, MA: Harvard University Press.

Rogers, Sarah, Jon Barnett, Michael Webber, Brian Finlayson and Mark Yaolin Wang. 2016. "Governmentality and the conduct of water: China's south-north water transfer project." Transactions of the Institute of British Geographers 41(4), 429-441.

Rogers, Sarah, and Britt Crow-Miller. 2017. "The politics of water: a review of hydropolitical frameworks and their application in China." WIREs Water. doi:10:1002/wat2.1239.

Rong, Hu. 2013. "Tieliu” (Iron flow). In Dianlong Cheng (ed.), Qiji jiu zheyang dansheng: Zhongguo zuojia nanshui beidiao dongxian hang (Thus a Miracle is Born: A Series of Chinese Authors on the South-North Water Transfer). Beijing: Zuojia chubanshe, 153-161.

Shaanxi Government. 2000. "Shaanxi sheng renmin zhengfu guanyu yinfa Huanghe jingji xiezuoqu zai xibu dakaifa zhong jinyibu jiaqiang lianhe yu xiezuo de shishi yijian de tongzhi" (Shaanxi Provincial People's Government Notice concerning strengthening cooperation and coordination between the Yellow River economic cooperation zone and the "open up the west" development programme). Shaanxi zhengbao, 27 November, 16-20.

Shapiro, Judith. 2002. Mao's War against Nature: Politics and the Environment in Revolutionary China. New York: Cambridge University Press.

State Council. 2012. State Council Document No. 3. "Guowuyuan guanyu shixing zuiyange shuiziyuan guanli zhidu de yijian" (State Council opinion regarding the most strict water resource management system). Beijing: State Council.

Teng, Tse-hui. 1955. Report on the Multi-purpose Plan for Permanently Controlling the Yellow River and Exploiting its Water Resources. Beijing: Foreign Languages Press.

Tilt, Brian. 2014. Dams and Development in China: The Moral Economy of Water and Power. New York: Columbia University Press. 
UN Food and Agriculture Organization. 2016. Aquastat Database, http://www.fao.org/nr/water/ aquastat/countries_regions/chn/index.stm. Accessed 10 December 2016.

US Joint Publications Research Service. 1965. Water Resources of China: Plans and Prospects for Development. Washington, DC: Clearinghouse for Federal Scientific and Technical Information.

Wang, Raymond Yu, Cho Nam Ng, James Hans Lenzer, Heping Dang, Tao Liu and Shenjun Yao. 2017. "Unpacking water conflicts: a reinterpretation of coordination problems in China's watergovernance system.” International Journal of Water Resources Development 33(4), 553-569.

Wang, Weiluo. 1999. "Zhongguo fangxun juece tizhi he shuizai chengyin fenxi" (Analysis of China's flood control system and the causes of flood disasters). Modern China Studies 3, http://www. modernchinastudies.org/us/issues/past-issues/66-mcs-1999-issue-3/505-2012-01-01-10-06-23.html.

Wang, Weiluo. 2002. "Water management in the People's Republic of China." In Manas Chatterji, Saul Arlosoroff and Gauri Guha (eds.), Conflict Management of Water Resources. Aldershot: Ashgate, 88-115.

Webber, Michael, Britt Crow-Miller and Sarah Rogers. 2017. "The south-north water transfer project: remaking the geography of China.” Regional Studies 51(3), 370-382.

Webber, Michael, and Xiao Han. 2017. "Corporations, governments, and socioenvironmental policy in China: China's water machine as assemblage." Annals of the American Association of Geographers 107(6), 1444-60.

Wittfogel, Karl. 1957. Oriental Despotism: A Comparative Study of Total Power. New Haven, CT: Yale University Press.

Wouters, Patricia, Desheng Hu, Jiebin Zhang, A. Dan Tarlock and Philip Andrews-Speed. 2004. "The new development of water law in China." University of Denver Water Law Review 7(2), 243-308.

Wu, Wencong. 2012. "Water plan to take effect by 2012." China Daily, 11 June, http://www. chinadaily.com.cn/china/2012-06/11/content_15491752.htm. Accessed 5 December 2012.

Xia, Chun, and Claudia Pahl-Wostl. 2012. "The process of innovation during transition to a watersaving society in China." Water Policy 14, 447-469.

Xiong, Yonglan, Yongping Wei, Zhiqiang Zhang and Jing Wei. 2016. "Evolution of China's water issues as framed in a Chinese mainstream newspaper." Ambio 45(2), 241-253.

Yellow River Sanmenxia Water Conservancy Project Editorial Committee. 1993. Huanghe Sanmenxia shuili shuniu zhi (History of the Yellow River Sanmenxia Water Conservancy Project). Beijing: Zhongguo dabaike quanshu chubanshe.

YRCC (Yellow River Conservancy Commission). 1991. Huanghe guihuazhi (History of Yellow River Planning). Vol. 6. Zhengzhou: Henan renmin chubanshe.

YRCC. 1995. Dongying shi Huanghe zhi (History of the Yellow River at Dongying City). Shandong: Qilu shushe.

YRCC Yellow River History Editorial Office. 1986. Henan Huanghezhi (Yellow River History of Henan). Zhengzhou: YRCC.

Zhang, Guang Xin, and Wei Deng. 2002. "Groundwater crisis and sustainable agriculture in northern China." Water \& Wastes Digest, 26 March, http://www.wwdmag.com/desalination/groundwatercrisis-and-sustainable-agriculture-northern-china. Accessed 15 October 2014.

Zhang, Ling. 2016. The River, the Plain, and the State: An Environmental Drama in Northern Song China, 1048-1128. New York: Cambridge University Press. 